\title{
Frameworks on Patterns of Grasslands' Sensitivity to Forecast Extreme Drought
}

\author{
Taofeek O. Muraina ${ }^{1,2}$ (1) \\ 1 National Hulunber Grassland Ecosystem Observation and Research Station, Institute of Agricultural \\ Resources and Regional Planning, Chinese Academy of Agricultural Sciences, Beijing 100081, China; \\ too.muraina@gmail.com \\ 2 Department of Animal Health and Production, Oyo State College of Agriculture and Technology, P.M.B. 10, \\ Igbo-Ora 201103, Oyo State, Nigeria
}

Received: 23 July 2020; Accepted: 30 August 2020; Published: 23 September 2020

\begin{abstract}
Climate models have predicted the future occurrence of extreme drought (ED). The management, conservation, or restoration of grasslands following ED requires a robust prior knowledge of the patterns and mechanisms of sensitivity-declining rate of ecosystem functions due to ED. Yet, the global-scale pattern of grasslands' sensitivity to any ED event remains unresolved. Here, frameworks were built to predict the sensitivity patterns of above-ground net primary productivity (ANPP) spanning the global precipitation gradient under ED. The frameworks particularly present three sensitivity patterns that could manipulate (weaken, strengthen, or erode) the orthodox positive precipitation-productivity relationship which exists under non-drought (ambient) condition. First, the slope of the relationship could become steeper via higher sensitivity at xeric sites than mesic and hydric ones. Second, if the sensitivity emerges highest in hydric, followed by mesic, then xeric, a weakened slope, flat line, or negative slope would emerge. Lastly, if the sensitivity emerges unexpectedly similar across the precipitation gradient, the slope of the relationship would remain similar to that of the ambient condition. Overall, the frameworks provide background knowledge on possible differences or similarities in responses of grasslands to forecast ED, and could stimulate increase in conduct of experiments to unravel the impacts of ED on grasslands. More importantly, the frameworks indicate the need for reconciliation of conflicting hypotheses of grasslands' sensitivity to ED through global-scale experiments.
\end{abstract}

Keywords: ANPP; climate extreme; diversity; ecosystem; global change; historical drought; precipitation

\section{Introduction}

Grassland is one of the major terrestrial ecosystems worldwide. It is distributed across a wide range of climates, elevations, and soil types [1,2]. Grassland delivers fodder for herbivores, renders aesthetic values, serves as biodiversity reservoirs, controls erosion, regulates climate (e.g., carbon sequestration) [3,4] and many more. These functions are naturally dependent on climate dynamics $[3,5,6]$, and they respond in diverse ways to the natural climate variability, as well as currently intensifying human-driven climate change [7]. Hence, the complexity of management, conservation and/or restoration of these natural ecosystems requires a robust understanding of the underlying mechanisms governing their response to the dynamics of climate [8].

Precipitation is an essential driver of most terrestrial ecosystem processes [9]. It is widely regarded as the primary abiotic factor limiting most ecosystem functions (e.g., above-ground net primary productivity (ANPP), diversity) in grasslands [5,10-14]. Meanwhile, global climate models have predicted the occurrence of unprecedented extreme drought (ED) conditions at the end of this 
century $[15,16]$. These ED conditions are expected to be statistically rare or unusual drought episodes far beyond the climax of historical record of droughts in any region of the world $[17,18]$. The ED could be rare within seasons or multi-year drought periods and could alter natural grasslands beyond that of typical interannual climate variability $[9,17,19-21]$. This may lead to severe loss of dominant life forms, species re-ordering, or shifts in plant community composition, triggered by disruptions in the interconnected complex ecological processes (e.g., nutrient cycling; Figure 1). The magnitude of the ecosystem alterations would largely depend on the period and magnitude of the ED events, stage of plants' growth cycle [22], the severity of changes, and resistance or recovery capacity of ecosystems after ED events $[8,23]$. With these uncertainties threatening the efficient delivery of ecosystem services, there is need for an in-depth understanding of how global or regional natural grasslands will respond to the ED $[17,24,25]$.



Figure 1. Conceptual diagram of how extreme drought could broadly impact grassland structure and functions. Extreme drought (ED) events could directly affect plants through decline in above-ground net primary productivity (ANPP), loss of diversity, or change in plant composition (filled brown arrow I and open brown arrows from the Plants). The ED could directly affect soil activities by altering soil microbial diversity, composition, and processes (filled brown arrow II), or indirectly through the loss of plant cover (filled brown arrow II) that could expose the soil to moisture loss, and inhibit the belowground net primary productivity (BNPP), activities of soil microbes, nutrient cycling, and others (opened brown arrows from the Soil). There is possibility of negative feedback effects of ED on the diversity and ANPP of drought-resistant plants that tolerate drought through belowground traits (opened black arrows from the Soil). Highlighted segment of the diagram represents the rhizosphere. Source: Author (Taofeek O. Muraina).

Certainly, previous investigations which were initiated following unusual or extreme drought events $[17,26,27]$ have significantly created a strong background of the likely response patterns of grasslands to extreme climate changes [17]. The recent predictions of future ED events have also birthed the use of rainout shelters to impose and study ED effects on ecosystem functions across a wide range of ecosystems $[9,20,24,28-32]$. However, these studies are still unevenly distributed around the world [24], with differences in drought levels, many findings on single-site effects, and few comparisons of responses between sites [9,31-35]. They are yet to give a clear and broad pattern of how the essential functions of grasslands (e.g., ANPP, species diversity) spanning global precipitation or aridity zones (Table 1) could respond to a uniform extreme drought, e.g., $\sim 80 \%$ growing season precipitation reduction. Therefore, for thorough understanding of the patterns and mechanisms underpinning 
grassland response to future ED, there is need for wide adoption and implementation of multisite coordinated experiments with similar drought treatments [36] and measurement protocols [20,36-39].

Table 1. Grassland classification along precipitation or aridity gradient.

\begin{tabular}{ccccc}
\hline Grassland Class & Precipitation Zones & AI (MAP/MPET) & MAP (mm $\left.\mathbf{~ r r}^{-\mathbf{1}}\right)$ & Global Land Cover (\%) \\
\hline Xeric & Extreme-arid & $<0.05$ & $<100$ & 7.5 \\
Xeric & Arid & $0.05-0.2$ & $100-250$ & 12.1 \\
Mesic & Semi-arid & $0.2-0.5$ & $250-600$ & 17.7 \\
Mesic & Dry-subhumid & $0.5-0.65$ & $600-1200$ & 9.9 \\
Hydric & Humid & $>0.65$ & $>1200$ & 39.2 \\
\hline
\end{tabular}

This table and information therein were adapted from $[2,5]$. AI = aridity index; $\mathrm{MAP}=$ mean annual precipitation; MPET $=$ mean annual potential evapotranspiration.

In anticipation of more experiments and/or expansion of the existing ones that would address these gaps, conceptual frameworks could be built from the synthesis of literature to explain possible trends that will guide and/or aid general understanding of the response patterns of grasslands to ED. The sensitivity patterns can be studied through well-documented ecological precipitation-productivity relationship which is fundamental to management of grassland ecosystems [40]. Here, I propose frameworks for predicting the possible sensitivity-declining rate of an ecosystem function in response to the ED-patterns of ANPP spanning global precipitation gradient. The frameworks were particularly built to understand how the sensitivity of ANPP of natural grasslands spanning global precipitation zones (Table 1) could manipulate (weaken, strengthen, or erode) the orthodox positive precipitation-productivity. Thus, for the purpose of this study, the global grasslands were classified into three broad groups (xeric, mesic, and hydric) based on global aridity levels (Table 1; [2]). To allow a comparable assessment of the global-scale sensitivity, the frameworks (Figure 2) were generally built on four assumptions. First, it was assumed that the magnitude of the ED would be relatively uniform across the precipitation (or aridity) gradient. Second, the magnitude of sensitivity would be relative to the historical record of ANPP in every grassland. Third, the means of ANPP naturally differ across the gradient under ambient conditions. Lastly, the magnitude and direction of the relationship (slopes) would be contingent upon the sensitivity levels of the xeric and hydric grasslands. In the following sections, I present the existing hypotheses on possible patterns of grasslands' sensitivity to extreme drought; develop frameworks depicting the sensitivity patterns; review mechanisms and dynamics that could support each framework; and make recommendations on how to reconcile the contrasting hypotheses.


Figure 2. Hypothetical frameworks of extreme drought (ED) effects on the precipitation-ANPP relationship. (I) The slope of the relationship found under ambient condition could become steeper via higher ANPP sensitivity to the ED at xeric sites than mesic and hydric ones. (II) If the ANPP sensitivity emerges highest in hydric, followed by mesic, then xeric, a reduced slope, flat line, or negative slope may emerge. (III) If the sensitivity is strikingly similar across the precipitation gradient, the slope would remain as it was under the ambient condition. Source: Author (Taofeek O. Muraina). 


\section{How Will Extreme Drought Impact Productivity of Grasslands?}

Ecologists often project the future status of the structure and processes of the earth system via earth system models [41,42]. Such models typically encompass land models which forecast the future state of terrestrial ecosystems [41]. For this reason, productivity, which is a key function of terrestrial ecosystems, and particularly the precipitation-productivity relationship, are part of the evaluation indices for the efficiency of the land models $[41,42]$. To date, there is consensus that strong positive correlation exists between precipitation and ANPP [10,29,40,43-45]. This is because photosynthesis, which is the main mechanism for plant growth and productivity, strongly couples with water [46]. However, intensified water deficits can manipulate this relationship $[29,47,48]$ given that all grasslands are open to water stress [49]. For instance, reports have shown that the current dwindling seasonal distribution of precipitation, in both size and frequency [50], causes divergent sensitivity of ANPP across different grasslands [27,44]. As extreme drought looms in some regions of the world in the future $[16,17,41,51]$, prior understanding of how ANPP may be affected are now much required $[17,27]$.

There exist two contrasting hypotheses suggesting opposing sensitivity patterns along the precipitation gradient. The first hypothesis (A) holds that precipitation is less of a limiting resource in hydric and mesic grasslands, unlike in xeric ones (Table 1). Thus, this hypothesis suggests that the highest sensitivity would occur in xeric followed by mesic, then hydric $[9,43]$. The alternative hypothesis (B) suggests a reverse sensitivity ranking (hydric $>$ mesic $>$ xeric) because xeric grasslands, unlike mesic and hydric ones, are characterized by high aridity and should be constituted by drought-tolerant plant species [52-54]. These xeric plants are known to be drought-tolerant because they maintain their aerial growth and photosynthetic activities under low plant water potentials without xylem cavitation [54-56]. In other words, the second hypothesis proposes relatively minimal sensitivity in grasslands experiencing naturally high aridity prior to the ED (low aridity index grasslands; Table 1).

\subsection{Frameworks of Sensitivity Patterns}

Given the known dependence of plant productivity on precipitation, and in line with the two aforementioned opposing hypotheses (A and B) and intuition, there are three possible patterns (Figure 2) of sensitivity with which ED could manipulate the positive precipitation-ANPP relationship. Each of the three patterns depend on which grassland class along the precipitation gradient would experience higher and least sensitivity to drought. Any of these patterns could emerge because all natural grasslands are open to the potential ED-driven reduction of soil water availability, high evapotranspiration, decrease in soil microbial activities, poor nutrient mineralization and availability, and inhibition of nutrient uptake (Figure 1; [22,57-61]). However, the coping mechanisms of different species that constitute every grassland will largely determine the magnitude of their sensitivity [62]. Generally, plants tolerate drought via non-mutually exclusive hydraulic and photosynthetic adjustments [63]. For instance, stomatal could adjust carbon assimilation regimes and transpiration rate to achieve optimal productivity and prevent desiccation during drought [63]. Plants can also cope with ED by increasing the rates of absorption and translocation of water from root to other organs [49]. Whichever grassland class (xeric, mesic, or hydric) is dominated by plants that have the wherewithal (one or more drought-tolerance traits), and in which the coping mechanisms supersede, would experience less sensitivity than others. Therefore, the sensitivity could be higher in xeric, than the mesic and hydric sites as depicted in framework I (Figure 2; left panel; slope I); or unfold in opposite directions as illustrated in framework II (Figure 2; middle panel; slopes IIa-c); or a strikingly similar sensitivity occurs across the gradient (framework III; Figure 2; right panel; slope III).

\subsubsection{Framework I}

If the precipitation-ANPP relationship evolved in consonance with the first hypothesis (hypothesis A), the ANPP of xeric grasslands would exhibit greater sensitivity to ED, compared with mesic or hydric ecosystems $[9,27,43]$, and the positive slope of the relationship would become steeper or strengthened 
(Figure 2; left panel; slope I). One possible mechanism that could promote this framework I is the existence of positive precipitation-species richness relationship [64-69] and the fact that ANPP is a cumulative of all species in a particular ecosystem. If higher precipitation promotes species richness and ANPP across the precipitation gradient, it is expected that the xeric and mesic grasslands would possess less species richness and ANPP compared with hydric. Therefore, it can be inferred, that hydric (and mesic) grasslands stand a higher chance of possessing a pool of species with diverse drought-tolerance traits that would lessen their sensitivity to drought than the xeric ones $[23,26,70,71]$. For example, the hydric ecosystems may have higher number of plants with greater root length density for capturing soil water from the deeper soil depth [72-75], plants that would maintain photosynthesis through dehydration-tolerance of lamina and osmotic adjustment $[55,76]$, or C4 and CAM (crassulacean acid metabolism) plants that subsist under water deficit [49,77]. The virtue of high species richness in hydric and mesic could also avail them the possession of those species that can switch from C3 to CAM metabolism to survive a prolonged ED $[49,78]$. Apart from drought-tolerance traits, community dynamics like species re-ordering, changes in species composition [79,80], and species asynchrony [1,81-85] are more likely in diverse communities and could minimize sensitivity in hydric grasslands than others. For instance, drought might trigger a shift in the competition for resources, structure, and abundance within highly diverse communities by favoring drought-tolerant subordinate species that would compensate for a possible higher sensitivity of the ED-intolerant dominant species $[33,86]$. This implies that species-rich ecosystems, unlike the species-poor ones, have a higher chance of possessing more subordinates and more rare species that may be more tolerant to ED and lessen the productivity loss by the dominants.

Indeed, the emergence of this framework I would contradict the notion that plant communities in drylands may be more tolerant to the effects of ED $[53,87]$. However, it may be that the unprecedented intensity of the ED would force the majority of the supposed drought-tolerant plants in drylands to exhibit drought-avoiding traits, thereby resulting to drastic reduction under ED. As ED avoiders, they could shed leaves, close stomata, redirect stored resources for increased below-ground productivity [88,89], and use more water from greater soil depths [90] to prevent eventual death and promote efficient recovery after drought events [55]. Monitoring of the mortality rate during drought and recovery rate in post-drought period could reveal whether those xeric ecosystems are only dominated by drought-tolerant species, or species with both drought-avoiding and drought-tolerance traits $[25,74]$.

\subsubsection{Framework II}

If the sensitivity patterns emerge according to the second hypothesis (B), the xeric grasslands with high aridity (low AI) would exhibit a less response to ED than the less arid ones (mesic and hydric) $[53,91]$. As such, a weakened slope of the relationship (Figure 2; middle panel; $\mathrm{II}_{\mathrm{a}}$ ), flat line $\left(\mathrm{II}_{\mathrm{b}}\right)$, or negative slope $\left(\mathrm{II}_{\mathrm{c}}\right)$ would emerge. Emergence of a flat line or negative slope suggests that drought would have eroded the advantages that higher precipitation confers on grasslands in low aridity regions over those in high aridity regions. Any of the three patterns (slope IIa-c) in this framework II could unfold if the following conditions hold: (1) the supposed drought-tolerant plants are mainly domicile in xeric grasslands, and they could tolerate ED as they do for the non-extreme inter-annual water stress that characterize their ecosystems; (2) the mesic and hydric grasslands either have relatively negligible or no drought-tolerant species that could mitigate sensitivity as the xeric ones. In this case, plants in xeric grasslands could adjust and lessen sensitivity via higher allocation of assimilates to roots for enhanced water uptake from the deeper part of the soil [92,93], storage of water in shoots, reduced leaf area, and stomata opening at nights when transpiration is lower for $\mathrm{CO}_{2}$ capturing [49]. Similarly, there will be lesser sensitivity in xeric grasslands if all plants, or those that contribute the substantial proportion of their ANPP, exhibit partial stomatal opening, while those in the mesic and hydric grasslands exhibit total stomatal closure under ED. Hence, partial stomatal opening that permits certain level of $\mathrm{CO}_{2}$ uptake, photosynthesis, and minimal transpiration [49] would maintain a certain level of 
ANPP, while stomatal closure in plants without drought-tolerant traits (e.g., deep root) would lead to higher sensitivity and eventual mortality. Alternatively, any of the patterns in this framework II could emerge if higher soil evapotranspiration rate, persistent high water-use, and non-closure of stomata of plants [94,95] force greater depletion of soil moisture, hydraulic failure, and eventual mortality of plants in hydric grasslands. Moreover, the usually less productive xeric grasslands, perhaps due to plants' adaptation to the dry conditions via conservative water-use [49], would experience less sensitivity than others if they experience lower soil evapotranspiration rate or lower soil moisture depletion [94].

Non-rainfall water (NRW) deposition is another phenomenon that could mitigate drought effects (sensitivity) $[96,97]$ in grasslands. The NRW events, such as fog, dew, hoar frost, and water vapor adsorption, occur without rainfall [96,98], and plants could utilize them through foliar/canopy [99-101] or shallow root uptake [96]. Plants with rough and permeable leaves [100], and higher leaf area index have higher chance of capturing more NRW that could aid drought tolerance [97]. Persistence of this phenomenon under ED could promote efficient stomata conductance, reduce transpiration, increase carbon assimilation [96,102-105], and maintain production [106]. Despite the wide reportage of occurrence of NRW deposition in ecosystems [104,107], studies eliciting direct evidence of their ecological impacts on grassland functions-e.g., positive effect of dew on ANPP [100]—are extremely rare. Most previous studies suggest that contribution of NRWs to annual precipitation varies across sites and climate zones [104]. Groh and colleagues, for instance, found that dew and hoar frost contributed about $4.2-6 \%$ of the total annual precipitation, and $16.1 \%$ of total monthly precipitation in drier months across two grasslands [104]. In semi-arid areas of Madagascar, dew contributed about $19 \%$ of average annual rainfall of which $41 \%$ occurred during dry months [105]. Baier [108] reported that dew constitute $2 \%$ of the average annual rainfall in semi-arid climatic conditions of South Africa. These variations in the intensity of NRW events can influence differential sensitivity to extreme drought amongst grasslands across global aridity zones (Table 1). Moreover, the reports that dew contributes more to water budgets through its higher frequency and duration in arid areas than in humid areas [109] suggests that NRWs are high in xeric than mesic and hydric. Consequently, it is argued that if indeed the hypothesis of a lesser sensitivity in xeric grasslands would be true [53], higher intensity or efficient-use of NRW events should be one of the underlying factors conferring higher drought tolerance on plants in xeric sites [110]. Thus, it can be hypothesized that framework II could prevail under ED, if higher intensity of NRWs deposition and presence of plants that can efficiently capture/utilize them prevail in xeric grasslands than the mesic and hydric. With that, the xeric would experience a less sensitivity than the mesic and the hydric grasslands.

\subsubsection{Framework III}

Here a new hypothesis $(\mathrm{C})$ is proposed that the three classes of grassland across the precipitation gradient could exhibit relatively similar sensitivity to the ED. This similar sensitivity across the gradient would result to a downward shift in the relationship, with little or no significant change in the slope (Figure 2, right panel; slope III). It is noteworthy that this hypothesis, unlike the previous two frameworks, has no scientific precedence, but it is not naturally impossible. For instance, this third hypothesis may ensue when the aforementioned potential conditions and adaptation traits that might confer a lesser sensitivity to hydric (in framework I) and xeric (in framework II) grasslands concurrently confer similar levels of low sensitivity to both grassland classes. One important mechanism that might bring about this relatively similar sensitivity is the extremely high similarity (or extremely low dissimilarity) in ecophysiological trait composition (e.g., drought-tolerant traits) amongst grasslands across the precipitation gradient [111]. This homogenization of ecophysiological traits is attainable through the increasing conscious and unconscious human movement of species into regions beyond their historical biogeographic realms [112,113]. So, the proposed framework III could ensue, when some species that are characteristically drought-tolerant and native to xeric grasslands spread into, naturalize, 
and proliferate in mesic and hydric grasslands [114,115] prior to ED events and become the dominant species under ED.

\section{Conclusions}

Now that current and future hydrological changes threaten grassland ecosystems in relation to the efficient delivery of their services [17,36], ecologists are currently faced with hurdles to predict how ecosystems will respond to these escalating climate changes [36]. As biodiversity conservation, productivity management programs, and sustainability policies vis-à-vis future occurrences on natural ecosystems depend on the predictive knowledge of extreme drought events, I herein provide insights and foresights to probable models with which grasslands might respond to the ED. Drawing from previous reports, hypotheses, and thoughts, I systematically built frameworks of possible shifts in the magnitude and direction of the precipitation-ANPP relationship for understanding how the ED may impact regional or global natural grasslands. Although the proposed frameworks may not be exhaustive, or exhibited as stated per se, they could stimulate the required attentions of ecologists and agroecologists, and provide background knowledge on possible differences or similarities amongst grasslands in response to forecast ED. The frameworks particularly highlight the pressing need for comprehensive studies that would reconcile the aforementioned contrasting sensitivity hypotheses and elicit all possible mechanisms underlying eventual sensitivity pattern under predicted ED conditions. Prior understanding of how the ED impacts grasslands, and how the mechanisms could vary from xeric to mesic and hydric grasslands, would guide grassland managers in designing and applying appropriate management programs for different natural grasslands based on their peculiarities. I am aware that adequate understanding and reconciliation of the conflicting hypotheses of grasslands' sensitivity addressed herein demands global-scale standardized experiments in which extreme drought of the same magnitude is imposed over a long time. Therefore, I recommend wide adoption and implementation of existing global-scale extreme drought studies (e.g., Drought-Net. Available online: https://drought-net.colostate.edu/; accessed on 26 August 2020) to aid substantial spread across the global precipitation gradient and provision of solutions to herein highlighted knowledge gaps.

Funding: This research was funded by NATIONAL KEY R\&D PROGRAM OF CHINA, 2017YFA0604802 and NATIONAL NATURAL SCIENCE FOUNDATION OF CHINA, 41320104002.

Acknowledgments: I profoundly appreciate Qiang Yu of IARRP-CAAS, Beijing for his guidance and provision of financial support for this publication. I also thank Saheed O. Jimoh of Grassland Research Institute of CAAS, Hohhot, and Suleiman K. Bello of King Abdulaziz University, Jeddah for their invaluable comments on the idea and draft that birthed this final manuscript.

Conflicts of Interest: The author declare no conflict of interest. The funders had no role in the design, writing, or the decision to publish the manuscript.

\section{References}

1. Stevens, C.J. Recent advances in understanding grasslands. F1000Research 2018, 7, F1000 Faculty Rev-1363. [CrossRef] [PubMed]

2. White, R.P.; Murray, S.; Rohweder, M. Pilot Analysis of Global Ecosystems: Grassland Ecosystems; World Resources Institute: Washington, DC, USA, 2000.

3. Staudinger, M.D.; Grimm, N.B.; Staudt, A.; Carter, S.L.; Stuart, F.S., III; Kareiva, P.; Ruckelshaus, M.; Stein, B.A. Impacts of Climate Change on Biodiversity, Ecosystems, and Ecosystem Services: Technical Input to the 2013 National Climate Assessment; United States Global Change Research Program: Washington, DC, USA, 2012; pp. i-A-6.

4. Bengtsson, J.; Bullock, J.M.; Egoh, B.; Everson, C.; O'Connor, T.; O’Farrell, P.J.; Smith, H.G.; Lindborg, R.; Everson, T. Grasslands-more important for ecosystem services than you might think. Ecosphere 2019, 10, e02582. [CrossRef]

5. Safriel, U.; Adeel, Z.; Niemeijer, D.; Puigdefabregas, J.; White, R.; Lal, R.; Winslow, M.; Ziedler, J.; Prince, S.; Archer, E.; et al. Dryland systems. In Ecosystems and Human Well-Being: Current State and Trend; Hassan, R., Scholes, R., Ash, N., Eds.; Island Press: Washington, DC, USA, 2005; pp. 623-662. 
6. Maestre, F.T.; Eldridge, D.J.; Soliveres, S.; Kéfi, S.; Delgado-Baquerizo, M.; Bowker, M.A.; García-Palacios, P.; Gaitán, J.; Gallardo, A.; Lázaro, R.; et al. Structure and functioning of dryland ecosystems in a changing world. Annu. Rev. Ecol. Evol. Syst. 2016, 47, 215-237. [CrossRef] [PubMed]

7. Grimm, N.B.; Chapin III, F.S.; Bierwagen, B.; Gonzalez, P.; Groffman, P.M.; Luo, Y.; Melton, F.; Nadelhoffer, K.; Pairis, A.; Raymond, P.A.; et al. The impacts of climate change on ecosystem structure and function. Front. Ecol. Environ. 2013, 11, 474-482. [CrossRef]

8. Blair, J.M.; Nippert, J.B.; Briggs, J. Grassland Ecology. In Ecology and the Environment; Monson, R.K., Ed.; Springer New York: New York, NY, USA, 2013; pp. 1-30.

9. Cherwin, K.L.; Knapp, A. Unexpected patterns of sensitivity to drought in three semi-arid grasslands. Oecologia 2012, 169, 845-852. [CrossRef]

10. Sala, O.E.; Parton, W.J.; Joyce, L.A.; Lauenroth, W.K. Primary Production of the Central Grassland Region of the United States. Ecology 1988, 69, 40-45. [CrossRef]

11. Yahdjian, L.; Sala, O.E. A rainout shelter design for intercepting different amounts of rainfall. Oecologia 2002, 133, 95-101. [CrossRef]

12. Yahdjian, L.; Sala, O.E. Climate change impacts on south american rangelands. Rangelands 2008, 30, 34-39. [CrossRef]

13. Gherardi, L.A.; Sala, O.E. Automated rainfall manipulation system: A reliable and inexpensive tool for ecologists. Ecosphere 2013, 4, 18. [CrossRef]

14. Collins, S.L.; Koerner, S.E.; Plaut, J.A.; Okie, J.G.; Brese, D.; Calabrese, L.B.; Carvajal, A.; Evansen, R.J.; Nonaka, E. Stability of tallgrass prairie during a 19-year increase in growing season precipitation. Funct. Ecol. 2012, 26, 1450-1459. [CrossRef]

15. Xu, C.; McDowell, N.G.; Fisher, R.A.; Wei, L.; Sevanto, S.; Christoffersen, B.O.; Weng, E.; Middleton, R.S. Increasing impacts of extreme droughts on vegetation productivity under climate change. Nat. Clim. Chang. 2019, 9, 948-953. [CrossRef]

16. IPCC. Summary for policy makers. In Climate Change 2013: The Physical Science Basis. Contribution of Working Group 1 to the Fifth Assessment Report of the Intergovernmental Panel on Climate Change; Stocker, T.F., Qin, D., Plattner, G.-K., Tignor, M., Allen, S.K., Doschung, J., Nauels, A., Xia, Y., Bex, V., Midgley, P.M., Eds.; Cambridge University Press (CUP): Cambridge, UK; New York, NY, USA, 2013; pp. 2-21.

17. Smith, M.D. An ecological perspective on extreme climatic events: A synthetic definition and framework to guide future research. J. Ecol. 2011, 99, 656-663. [CrossRef]

18. De Boeck, H.J.; Bloor, J.M.G.; Kreyling, J.; Ransijn, J.C.G.; Nijs, I.; Jentsch, A.; Zeiter, M. Patterns and drivers of biodiversity-stability relationships under climate extremes. J. Ecol. 2018, 106, 890-902. [CrossRef]

19. Heisler-White, J.L.; Blair, J.M.; Kelly, E.F.; Harmoney, K.; Knapp, A.K. Contingent productivity responses to more extreme rainfall regimes across a grassland biome. Glob. Chang. Biol. 2009, 15, 2894-2904. [CrossRef]

20. Knapp, A.K.; Avolio, M.L.; Beier, C.; Carroll, C.J.W.; Collins, S.L.; Dukes, J.S.; Fraser, L.H.; Griffin-Nolan, R.J.; Hoover, D.L.; Jentsch, A.; et al. Pushing precipitation to the extremes in distributed experiments: Recommendations for simulating wet and dry years. Glob. Chang. Biol. 2016, 23, 1774-1782. [CrossRef]

21. De Boeck, H.J.; Verbeeck, H. Drought-associated changes in climate and their relevance for ecosystem experiments and models. Biogeosciences 2011, 8, 1121-1130. [CrossRef]

22. Bista, D.R.; Heckathorn, S.A.; Jayawardena, D.M.; Mishra, S.; Boldt, J.K. Effects of drought on nutrient uptake and the levels of nutrient-uptake proteins in roots of drought-sensitive and -tolerant grasses. Plants (Basel) 2018, 7, 28. [CrossRef]

23. Van Ruijven, J.; Berendse, F. Diversity enhances community recovery, but not resistance, after drought. J. Ecol. 2010, 98, 81-86. [CrossRef]

24. Hoover, D.L.; Wilcox, K.R.; Young, K.E. Experimental droughts with rainout shelters: A methodological review. Ecosphere 2018, 9, e02088. [CrossRef]

25. Wellstein, C.; Poschlod, P.; Gohlke, A.; Chelli, S.; Campetella, G.; Rosbakh, S.; Canullo, R.; Kreyling, J.; Jentsch, A.; Beierkuhnlein, C. Effects of extreme drought on specific leaf area of grassland species: A meta-analysis of experimental studies in temperate and sub-mediterranean systems. Glob. Chang. Biol. 2017, 23, 2473-2481. [CrossRef]

26. Tilman, D.; Downing, J.A. Biodiversity and stability in grasslands. Nature 1994, 367, 363-365. [CrossRef]

27. Knapp, A.K.; Carroll, C.J.; Denton, E.M.; La Pierre, K.J.; Collins, S.L.; Smith, M.D. Differential sensitivity to regional-scale drought in six central US grasslands. Oecologia 2015, 177, 949-957. [CrossRef] 
28. Koerner, S.E.; Collins, S.L. Interactive effects of grazing, drought, and fire on grassland plant communities in North America and South Africa. Ecology 2014, 95, 98-109. [CrossRef] [PubMed]

29. Yahdjian, L.; Sala, O.E. Vegetation structure constrains primary production response to water availability in the patagonian steppe. Ecology 2006, 87, 952-962. [CrossRef]

30. Byrne, K.M.; Adler, P.B.; Lauenroth, W.K. Contrasting effects of precipitation manipulations in two Great Plains plant communities. J. Veg. Sci. 2017, 28, 238-249. [CrossRef]

31. Hoover, D.L.; Knapp, A.K.; Smith, M.D. Resistance and resilience of a grassland ecosystem to climate extremes. Ecology 2014, 95, 2646-2656. [CrossRef]

32. Zang, Y.-X.; Min, X.-J.; de Dios, V.R.; Ma, J.-Y.; Sun, W. Extreme drought affects the productivity, but not the composition, of a desert plant community in central Asia differentially across microtopographies. Sci. Total. Environ. 2020, 717, 137251. [CrossRef] [PubMed]

33. Castillioni, K.; Wilcox, K.; Jiang, L.; Luo, Y.; Jung, C.G.; Souza, L. Drought mildly reduces plant dominance in a temperate prairie ecosystem across years. Ecol. Evol. 2020, 10, 6702-6713. [CrossRef]

34. Zhang, F.; Quan, Q.; Song, B.; Sun, J.; Chen, Y.; Zhou, Q.; Niu, S. Net primary productivity and its partitioning in response to precipitation gradient in an alpine meadow. Sci. Rep. 2017, 7, 15193. [CrossRef]

35. Serafini, J.; Grogan, P.; Aarssen, L. Summer precipitation limits plant species richness but not overall productivity in a temperate mesic old-field meadow. J. Veg. Sci. 2019, 30, 832-844. [CrossRef]

36. Smith, M.D.; Wilcox, K.R.; Power, S.A.; Tissue, D.T.; Knapp, A.K. Assessing community and ecosystem sensitivity to climate change - toward a more comparative approach. J. Veg. Sci. 2017, 28, 235-237. [CrossRef]

37. Fraser, L.H.; Henry, H.A.L.; Carlyle, C.N.; White, S.R.; Beierkuhnlein, C.; Cahill, J.F.; Casper, B.B.; Cleland, E.; Collins, S.L.; Dukes, J.S.; et al. Coordinated distributed experiments: An emerging tool for testing global hypotheses in ecology and environmental science. Front. Ecol. Environ. 2013, 11, 147-155. [CrossRef]

38. Slette, I.J.; Post, A.K.; Awad, M.; Even, T.; Punzalan, A.; Williams, S.; Smith, M.D.; Knapp, A.K. How ecologists define drought, and why we should do better. Glob. Chang. Biol. 2019, 25, 3193-3200. [CrossRef] [PubMed]

39. Knapp, A.K.; Smith, M.D.; Hobbie, S.E.; Collins, S.L.; Fahey, T.J.; Hansen, G.J.A.; Landis, D.A.; La Pierre, K.J.; Melillo, J.M.; Seastedt, T.R.; et al. Past, Present, and Future Roles of Long-Term Experiments in the LTER Network. BioScience 2012, 62, 377-389. [CrossRef]

40. Paruelo, J.M.; Lauenroth, W.K.; Burke, I.C.; Sala, O.E. Grassland precipitation-use efficiency varies across a resource gradient. Ecosystems 1999, 2, 64-68. [CrossRef]

41. Estiarte, M.; Vicca, S.; Peñuelas, J.; Bahn, M.; Beier, C.; Emmett, B.A.; Fay, P.A.; Hanson, P.J.; Hasibeder, R.; Kigel, J.; et al. Few multiyear precipitation-reduction experiments find a shift in the productivity-precipitation relationship. Glob. Chang. Biol. 2016, 22, 2570-2581. [CrossRef]

42. Luo, Y.Q.; Randerson, J.T.; Abramowitz, G.; Bacour, C.; Blyth, E.; Carvalhais, N.; Ciais, P.; Dalmonech, D.; Fisher, J.B.; Fisher, R.; et al. A framework for benchmarking land models. Biogeosciences 2012, 9, 3857-3874. [CrossRef]

43. Huxman, T.E.; Smith, M.D.; Fay, P.A.; Knapp, A.K.; Shaw, M.R.; Loik, M.E.; Smith, S.D.; Tissue, D.T.; Zak, J.C.; Weltzin, J.F.; et al. Convergence across biomes to a common rain-use efficiency. Nature 2004, 429, 651-654. [CrossRef]

44. Knapp, A.K.; Smith, M.D. Variation Among Biomes in Temporal Dynamics of Aboveground Primary Production. Science 2001, 291, 481-484. [CrossRef]

45. Liu, L.; Cheng, J.; Liu, Y.; Sheng, J. Relationship of Productivity to Species Richness in the Xinjiang Temperate Grassland. PLoS ONE 2016, 11, e0154026. [CrossRef]

46. Osakabe, Y.; Osakabe, K.; Shinozaki, K. Plant Environmental Stress Responses for Survival and Biomass Enhancement. Clim. Chang. Plant Abiotic Stress Toler. 2013, 79-108. [CrossRef]

47. Shi, Z.; Thomey, M.L.; Mowll, W.; Litvak, M.; Brunsell, N.A.; Collins, S.L.; Pockman, W.; Smith, M.D.; Knapp, A.K.; Luo, Y. Differential effects of extreme drought on production and respiration: Synthesis and modeling analysis. Biogeosciences 2014, 11, 621-633. [CrossRef] 
48. Wilcox, K.R.; Shi, Z.; Gherardi, L.A.; Lemoine, N.P.; Koerner, S.E.; Hoover, D.L.; Bork, E.; Byrne, K.M.; Cahill, J., Jr.; Collins, S.L.; et al. Asymmetric responses of primary productivity to precipitation extremes: A synthesis of grassland precipitation manipulation experiments. Glob. Chang. Biol. 2017, 23, 4376-4385. [CrossRef] [PubMed]

49. Lombardini, L.; Rossi, L. Ecophysiology of Plants in Dry Environments; Springer: Berlin/Heidelberg, Germany, 2019; pp. 71-100.

50. Jia, X.; Xie, B.; Shao, M.A.; Zhao, C. Primary Productivity and Precipitation-Use Efficiency in Temperate Grassland in the Loess Plateau of China. PLoS ONE 2015, 10, e0135490. [CrossRef] [PubMed]

51. Smith, M.D.; La Pierre, K.J.; Collins, S.L.; Knapp, A.K.; Gross, K.L.; Barrett, J.E.; Frey, S.D.; Gough, L.; Miller, R.J.; Morris, J.T.; et al. Global environmental change and the nature of aboveground net primary productivity responses: Insights from long-term experiments. Oecologia 2015, 177, 935-947. [CrossRef] [PubMed]

52. Funk, J.L. The physiology of invasive plants in low-resource environments. Conserv. Physiol. $2013,1$. [CrossRef] [PubMed]

53. Grime, J.P.; Brown, V.K.; Thompson, K.; Masters, G.J.; Hillier, S.H.; Clarke, I.P.; Askew, A.P.; Corker, D.; Kielty, J.P. The Response of Two Contrasting Limestone Grasslands to Simulated Climate Change. Science 2000, 289, 762-765. [CrossRef]

54. Grime, J.P.; Fridley, J.D.; Askew, A.P.; Thompson, K.; Hodgson, J.G.; Bennett, C.R. Long-term resistance to simulated climate change in an infertile grassland. Proc. Natl. Acad. Sci. USA 2008, 105, 10028-10032. [CrossRef]

55. Volaire, F.; Barkaoui, K.; Norton, M. Designing resilient and sustainable grasslands for a drier future: Adaptive strategies, functional traits and biotic interactions. Eur. J. Agron. 2014, 52, 81-89. [CrossRef]

56. McDowell, N.; Pockman, W.T.; Allen, C.D.; Breshears, D.D.; Cobb, N.; Kolb, T.; Plaut, J.; Sperry, J.; West, A.; Williams, D.G.; et al. Mechanisms of plant survival and mortality during drought: Why do some plants survive while others succumb to drought? New Phytol. 2008, 178, 719-739. [CrossRef]

57. He, M.; Dijkstra, F.A. Drought effect on plant nitrogen and phosphorus: A meta-analysis. New Phytol. 2014, 204, 924-931. [CrossRef]

58. Luo, W.; Xu, C.; Ma, W.; Yue, X.; Liang, X.; Zuo, X.A.; Knapp, A.K.; Smith, M.D.; Sardans, J.; Dijkstra, F.A.; et al. Effects of extreme drought on plant nutrient uptake and resorption in rhizomatous vs bunchgrass-dominated grasslands. Oecologia 2018, 188, 633-643. [CrossRef] [PubMed]

59. Sardans, J.; Peñuelas, J. The Role of Plants in the Effects of Global Change on Nutrient Availability and Stoichiometry in the Plant-Soil System. Plant Physiol. 2012, 160, 1741-1761. [CrossRef] [PubMed]

60. De Andrés, E.G. Interactions between Climate and Nutrient Cycles on Forest Response to Global Change: The Role of Mixed Forests. Forests 2019, 10, 609. [CrossRef]

61. de Vries, F.T.; Griffiths, R.I.; Knight, C.G.; Nicolitch, O.; Williams, A. Harnessing rhizosphere microbiomes for drought-resilient crop production. Science 2020, 368, 270-274. [CrossRef] [PubMed]

62. Chaves, M.M. Effects of Water Deficits on Carbon Assimilation. J. Exp. Bot. 1991, 42, 1-16. [CrossRef]

63. Hartzell, S. Ecohydrology of Photosynthesis; Springer: Berlin/Heidelberg, Germany, 2019; pp. 101-120.

64. Zhang, Q.; Hou, X.; Li, F.Y.; Niu, J.; Zhou, Y.; Ding, Y.; Zhao, L.; Li, X.; Ma, W.; Kang, S. Alpha, Beta and Gamma Diversity Differ in Response to Precipitation in the Inner Mongolia Grassland. PLoS ONE 2014, 9, e93518. [CrossRef]

65. Cleland, E.E.; Collins, S.L.; Dickson, T.L.; Farrer, E.C.; Gross, K.L.; Gherardi, L.A.; Hallett, L.; Hobbs, R.J.; Hsu, J.S.; Turnbull, L.; et al. Sensitivity of grassland plant community composition to spatial vs. temporal variation in precipitation. Ecology 2013, 94, 1687-1696. [CrossRef]

66. Adler, P.B.; Levine, J.M. Contrasting relationships between precipitation and species richness in space and time. Oikos 2007, 116, 221-232. [CrossRef]

67. Kreft, H.; Jetz, W. Global patterns and determinants of vascular plant diversity. Proc. Natl. Acad. Sci. USA 2007, 104, 5925-5930. [CrossRef]

68. Wu, J.; Shen, Z.; Zhang, X. Precipitation and species composition primarily determine the diversity-productivity relationship of alpine grasslands on the Northern Tibetan Plateau. Alp. Bot. 2014, 124, 13-25. [CrossRef] 
69. Fernandez-Going, B.M.; Anacker, B.L.; Harrison, S.P. Temporal variability in California grasslands: Soil type and species functional traits mediate response to precipitation. Ecology 2012, 93, 2104-2114. [CrossRef] [PubMed]

70. Yachi, S.; Loreau, M. Biodiversity and ecosystem productivity in a fluctuating environment: The insurance hypothesis. Proc. Natl. Acad. Sci. USA 1999, 96, 1463-1468. [CrossRef] [PubMed]

71. Griffin-Nolan, R.J.; Blumenthal, D.M.; Collins, S.L.; Farkas, T.E.; Hoffman, A.M.; Mueller, K.E.; Ocheltree, T.W.; Smith, M.D.; Whitney, K.D.; Knapp, A.K. Shifts in plant functional composition following long-term drought in grasslands. J. Ecol. 2019, 107, 2133-2148. [CrossRef]

72. Blum, A. Effective use of water (EUW) and not water-use efficiency (WUE) is the target of crop yield improvement under drought stress. Field Crop. Res. 2009, 112, 119-123. [CrossRef]

73. White, T.A.; Snow, V.O. A modelling analysis to identify plant traits for enhanced water-use efficiency of pasture. Crop. Pasture Sci. 2012, 63, 63-76. [CrossRef]

74. Poirier, M.; Durand, J.-L.; Volaire, F. Persistence and production of perennial grasses under water deficits and extreme temperatures: Importance of intraspecific vs. interspecific variability. Glob. Chang. Biol. 2012, 18, 3632-3646. [CrossRef]

75. Bardgett, R.D.; Mommer, L.; De Vries, F.T. Going underground: Root traits as drivers of ecosystem processes. Trends Ecol. Evol. 2014, 29, 692-699. [CrossRef]

76. Serraj, R.; Sinclair, T.R. Osmolyte accumulation: Can it really help increase crop yield under drought conditions? Plant Cell Environ. 2002, 25, 333-341. [CrossRef]

77. Pereira, P.N.; Cushman, J.C. Exploring the Relationship between Crassulacean Acid Metabolism (CAM) and Mineral Nutrition with a Special Focus on Nitrogen. Int. J. Mol. Sci. 2019, 20, 4363. [CrossRef]

78. Cushman, J.C.; Borland, A.M. Induction of Crassulacean acid metabolism by water limitation. Plant Cell Environ. 2002, 25, 295-310. [CrossRef] [PubMed]

79. Jones, S.K.; Ripplinger, J.; Collins, S.L. Species reordering, not changes in richness, drives long-term dynamics in grassland communities. Ecol. Lett. 2017, 20, 1556-1565. [CrossRef] [PubMed]

80. Collins, S.L.; Suding, K.N.; Cleland, E.E.; Batty, M.; Pennings, S.C.; Gross, K.L.; Grace, J.B.; Gough, L.; Fargione, J.E.; Clark, C.M. Rank clocks and plant community dynamics. Ecology 2008, 89, 3534-3541. [CrossRef] [PubMed]

81. Hector, A.; Hautier, Y.; Saner, P.; Wacker, L.; Bagchi, R.; Joshi, J.; Scherer-Lorenzen, M.; Spehn, E.M.; Bazeley-White, E.; Weilenmann, M.; et al. General stabilizing effects of plant diversity on grassland productivity through population asynchrony and overyielding. Ecology 2010, 91, 2213-2220. [CrossRef] [PubMed]

82. Isbell, F.I.; Polley, H.W.; Wilsey, B.J. Biodiversity, productivity and the temporal stability of productivity: Patterns and processes. Ecol. Lett. 2009, 12, 443-451. [CrossRef] [PubMed]

83. Ma, Z.; Liu, H.; Mi, Z.; Zhang, Z.; Wang, Y.; Xu, W.; Jiang, L.; He, J.-S. Climate warming reduces the temporal stability of plant community biomass production. Nat. Commun. 2017, 8, 15378. [CrossRef]

84. Grman, E.; Lau, J.A.; Schoolmaster, D.R.; Gross, K.L. Mechanisms contributing to stability in ecosystem function depend on the environmental context. Ecol. Lett. 2010, 13, 1400-1410. [CrossRef]

85. Craven, D.; Isbell, F.; Manning, P.; Connolly, J.; Bruelheide, H.; Ebeling, A.; Roscher, C.; Van Ruijven, J.; Weigelt, A.; Wilsey, B.; et al. Plant diversity effects on grassland productivity are robust to both nutrient enrichment and drought. Philos. Trans. R. Soc. B Biol. Sci. 2016, 371, 20150277. [CrossRef]

86. Mariotte, P.; Vandenberghe, C.; Kardol, P.; Hagedorn, F.; Buttler, A. Subordinate plant species enhance community resistance against drought in semi-natural grasslands. J. Ecol. 2013, 101, 763-773. [CrossRef]

87. Tucker, S.S.; Craine, J.M.; Nippert, J.B. Physiological drought tolerance and the structuring of tallgrass prairie assemblages. Ecosphere 2011, 2, 48. [CrossRef]

88. Valladares, F.; Sánchez-Gómez, D. Ecophysiological Traits Associated with Drought in Mediterranean Tree Seedlings: Individual Responses versus Interspecific Trends in Eleven Species. Plant Biol. 2006, 8, 688-697. [CrossRef] [PubMed]

89. Bielenberg, D.G. Knowing when not to grow. New Phytol. 2011, 189, 3-5. [CrossRef] [PubMed]

90. Nippert, J.B.; Knapp, A.K. Linking water uptake with rooting patterns in grassland species. Oecologia 2007, 153, 261-272. [CrossRef] 
91. Epstein, H.E.; Lauenroth, W.K.; Paruelo, J.M.; Piñeiro, G.; Burke, I.C.; Barrett, J.E. Interactions of Water and Nitrogen on Primary Productivity Across Spatial and Temporal Scales in Grassland and Shrubland Ecosystems; Springer: Berlin/Heidelberg, Germany, 2019; pp. 417-437.

92. Donovan, L.A.; Dudley, S.A.; Rosenthal, D.M.; Ludwig, F. Phenotypic selection on leaf water use efficiency and related ecophysiological traits for natural populations of desert sunflowers. Oecologia 2007, 152, 13-25. [CrossRef] [PubMed]

93. Chaves, M.M.; Pereira, J.S.; Marôco, J.P.; Rodrigues, M.L.; Ricardo, C.P.C.; Osório, M.L.; Carvalho, I.S.; Faria, T.; Pinheiro, C. How Plants Cope with Water Stress in the Field? Photosynthesis and Growth. Ann. Bot. 2002, 89, 907-916. [CrossRef]

94. Leitinger, G.; Ruggenthaler, R.; Hammerle, A.; Lavorel, S.; Schirpke, U.; Clement, J.-C.; Lamarque, P.; Obojes, N.; Tappeiner, U. Impact of droughts on water provision in managed alpine grasslands in two climatically different regions of the Alps. Ecohydrology 2015, 8, 1600-1613. [CrossRef]

95. Cocozza, C.; de Miguel, M.; Pšidová, E.; Ditmarová, L.; Marino, S.; Maiuro, L.; Alvino, A.; Czajkowski, T.; Bolte, A.; Tognetti, R. Variation in Ecophysiological Traits and Drought Tolerance of Beech (Fagus sylvatica L.) Seedlings from Different Populations. Front. Plant Sci. 2016, 7, 886. [CrossRef]

96. Wang, L.; Kaseke, K.F.; Seely, M.K. Effects of non-rainfall water inputs on ecosystem functions. Wiley Interdiscip. Rev. Water 2017, 4, e1179. [CrossRef]

97. Runyan, C.; Wang, L.; Lawrence, D.; D'Odorico, P. Ecohydrological Controls on the Deposition of Non-rainfall Water, N, and P to Dryland Ecosystems; Springer: Berlin/Heidelberg, Germany, 2019; pp. 121-137.

98. Kidron, G.J. Analysis of dew precipitation in three habitats within a small arid drainage basin, Negev Highlands, Israel. Atmos. Res. 2000, 55, 257-270. [CrossRef]

99. Martin, C.E.; von Willert, A.D.J. Leaf Epidermal Hydathodes and the Ecophysiological Consequences of Foliar Water Uptake in Species of Crassula from the Namib Desert in Southern Africa. Plant Biol. 2000, 2, 229-242. [CrossRef]

100. Sudmeyer, R.A.; Nulsen, R.A.; Scott, W.D. Measured dewfall and potential condensation on grazed pasture in the Collie River basin, southwestern Australia. J. Hydrol. 1994, 154, 255-269. [CrossRef]

101. Jia, Z.; Zhao, Z.; Zhang, Q.; Wu, W. Dew Yield and Its Influencing Factors at the Western Edge of Gurbantunggut Desert, China. Water 2019, 11, 733. [CrossRef]

102. Zhuang, Y.; Zhao, W.; Yanli, Z.; Wenzhi, Z. The ecological role of dew in assisting seed germination of the annual desert plant species in a desert environment, northwestern China. J. Arid. Land 2015, 8, $264-271$. [CrossRef]

103. Barradas, V.L.; Glez-Medellín, M.G. Dew and its effect on two heliophile understorey species of a tropical dry deciduous forest in Mexico. Int. J. Biometeorol. 1999, 43, 1-7. [CrossRef]

104. Groh, J.; Slawitsch, V.; Herndl, M.; Graf, A.; Vereecken, H.; Pütz, T. Determining dew and hoar frost formation for a low mountain range and alpine grassland site by weighable lysimeter. J. Hydrol. 2018, 563, 372-381. [CrossRef]

105. Hanisch, S.; Lohrey, C.; Buerkert, A. Dewfall and its ecological significance in semi-arid coastal south-western Madagascar. J. Arid. Environ. 2015, 121, 24-31. [CrossRef]

106. Kerr, J.P.; Beardsell, M.F. Effect of Dew on Leaf Water Potentials and Crop Resistances in a Paspalum Pasture1. Agron. J. 1907, 67, 596-599. [CrossRef]

107. Wang, L.; D’Odorico, P.; Evans, J.P.; Eldridge, D.J.; McCabe, M.F.; Caylor, K.K.; King, E.G. Dryland ecohydrology and climate change: Critical issues and technical advances. Hydrol. Earth Syst. Sci. 2012, 16, 2585-2603. [CrossRef]

108. Baier, W. Studies on dew formation under semi-arid conditions. Agric. Meteorol. 1966, 3, 103-112. [CrossRef]

109. Jia, Z.; Wang, Z.; Wang, H. Characteristics of Dew Formation in the Semi-Arid Loess Plateau of Central Shaanxi Province, China. Water 2019, 11, 126. [CrossRef]

110. Kaseke, K.F.; Wang, L.; Seely, M.K. Nonrainfall water origins and formation mechanisms. Sci. Adv. 2017, 3, e1603131. [CrossRef]

111. Winter, M.; Kühn, I.; La Sorte, F.A.; Schweiger, O.; Nentwig, W.; Klotz, S. The role of non-native plants and vertebrates in defining patterns of compositional dissimilarity within and across continents. Glob. Ecol. Biogeogr. 2010, 19, 332-342. [CrossRef] 
112. van Kleunen, M.; Dawson, W.; Essl, F.; Pergl, J.; Winter, M.; Weber, E.; Kreft, H.; Weigelt, P.; Kartesz, J.; Nishino, M.; et al. Global exchange and accumulation of non-native plants. Nature 2015, 525, 100-103. [CrossRef] [PubMed]

113. Simberloff, D.; Martin, J.-L.; Genovesi, P.; Maris, V.; Wardle, D.A.; Aronson, J.; Courchamp, F.; Galil, B.; García-Berthou, E.; Pascal, M.; et al. Impacts of biological invasions: What's what and the way forward. Trends Ecol. Evol. 2013, 28, 58-66. [CrossRef] [PubMed]

114. Catford, J.A.; Jones, L.P.; Gibson, D.J.; Newman, J.A. Grassland invasion in a changing climate. In Grasslands and Climate Change; Cambridge University Press (CUP): Cambridge, UK, 2019; pp. 149-171.

115. Liu, Y.; Oduor, A.M.O.; Zhang, Z.; Manea, A.; Tooth, I.M.; Leishman, M.R.; Xu, X.; van Kleunen, M. Do invasive alien plants benefit more from global environmental change than native plants? Glob. Chang. Biol. 2017, 23, 3363-3370. [CrossRef]

(C) 2020 by the author. Licensee MDPI, Basel, Switzerland. This article is an open access article distributed under the terms and conditions of the Creative Commons Attribution (CC BY) license (http://creativecommons.org/licenses/by/4.0/). 